\title{
THE IMPORTANCE OF UNDERSTOREY ON WILDLIFE IN A BRAZILIAN EUCALYPT PLANTATION
}

\author{
Jody R. Stallings ${ }^{1}$
}

\begin{abstract}
Wildlife surveys were conducted in two stands of Eucalyptus, one homogeneous and the other with a native species understorey in the Atlantic forest region of southeastern Brazil. Deforestation has reduced the original forested habitat to a patchwork of cultivated fields and mono-specific forestry plantations. Wildlife communities were depauperate in the homogeneous stand, but richer in eucalypt forest with native species understorey. Small mammals, particularly didelphid marsupials, used the understorey rather than the eucalypt emergent trees. Primates were absent from both areas. The increasing demand for charcoal for the growing steel industry in the region means that eucalypt plantations will persist until an alternative energy source is found. It is essential that management efforts be directed towards multi-use strategies in these plantations Eucalypt plantations with a native species understorey might provide sufficient habitat to support some wildlife species of the rapidly disappearing Atlantic coastal forest ecosystem.
\end{abstract}

\section{INTRODUCTION}

Plantations are generally perceived as unsuitable habitat for wildlife in temperate North America (NATIONAL ACADEMY PRESS, 1982; HARRIS AND SMITH, 1978; BAILEY AND ALEXANDER, 1960), in tropical Australia (FRIEND AND TAYLOR, 1985), as well as in Madagascar (GANZHORN, 1987) and Malaysia (WILSON AND JOHNS, 1982). The low wildlife diversity described by these studies is believed to result from the spatial and structural homogeneity which results in little wildlife food and cover and few resting sites (EVANS, 1982).

Although the negative effect of plantations has been well documented in other regions of the world, there has been little attention directed to wildlife communities in these habitats in tropical America (NATIONAL ACADEMY PRESS, 1982). Very few studies report on wildlife in plantations in Brazil (DIETZ ET AL., 1975; ALMEIDA, 1979): a serious -omission because, in 1960, 70\% of Latin America's Eucalyptus plantations occurred in this country (WADSWORTH, 1961). This paper reports on vertebrate communities sampled in two plantations of Eucalyptus saligna, one without an understorey and a second with a native species understorey, in the Rio Doce valley in southeastern Brazil. Faunal comparisons were made between these exotic stands and the native forest of a nearby protected area.

1. Programa de Mestrado em Conservação, Ecologia e Manejo de Vida Silvestre, Depto. Zoologia, ICB, Universidade Federal de Minas Gerais. 
FONSECA (1985a) reported on the fate of the Atlantic forest region of Brazil, a critically endangered ecosystem that has suffered extensive deforestation since the arrival of the Portuguese in the early 1500's. Cleared forests were used for cultivated crops and pasture, and sinœ the early 1900's for plantations, especially of the genus Eucalpytus. The Rio Doce valley occurs within this ecosystem and has suffered serious deforestation of the native forests for the production of crops and the establishment of exotic plantations of Eucalyptus (BAER, 1970; FONSECA, 1985a; STALLINGS, 1988).

Mammals and medium and large sized birds were surveyed each month from October, 1985, to September, 1986, in a homogeneous eucalypt stand and a stand of eucalypt forest with a native species understorey near the Rio Doce State Forestry Park.

The Rio Doce Park (35,000 ha.) is managed by the Minas Gerais State Forestry Institute and is one of the largest continuous tracts of Atlantic forest remaining today (Figura 1). The Park is surrounded by pastures, crops and approximately 15,000 ha. of Eucalyptus plantations. (STALLINGS, 1988). The last native forests in the vicinity of the Park were felled in 1956 (STALLINGS, 1988).

The two sites were within $2 \mathrm{~km}$ of the western entrance of the Park, at Salão Dourado (Figure 1) and consisted of Eucalyptus saligna planted in 1957. The homogeneous stand (RD/P) was cut eight years later in 1965, and after coppicing, was cut again in 1972 and 1979. In 1980, the area was replanted. The ground was covered with exotic grasses and the forest understorey was maintained free of native shrub and tree species. Eucalypt tree height averaged $18,5 \mathrm{~m}$ and ground cover approached $90 \%$.

The plantation with a native species understorey $(\mathrm{RD} / \mathrm{E})$ graded gradually into homogeneous eucalypt forest. It was cut selectively in 1964 and 1971 . The forest had not been cleaned (undergrowth control) since the 2nd or 3rd year after the 1971 cutting, resulting in a regeneration, mostly through coppicing, of a rich and diverse native species understorey, described by STALLINGS (1988). It was composed of more than 66 tree and shrub species with a diameter at breast height $(\mathrm{dbh})$ of $\geqslant 3,2 \mathrm{~cm}$. Numerically abundant species were Adenanthera peregrina, Ocotea corymbosa, Pouteria sp., Mabea fistulifera, Myrcia sp., and Vismia martiana. Mean height was $16,6 \mathrm{~m}$ for emergent eucalypt trees and $8,4 \mathrm{~m}$ for understorey shrubs and trees. Percent ground cover and canopy cover both averaged over $50 \%$. Ground cover varied spatially by bamboo and grass species, vines, and small shrubs.

\section{METHODS}

\section{Small Mammal Trapping}

The trapping methods were identical in the two sites. RD/P was not found to contain any medium to large sized terrestrial mammals which precluded the use of larger terrestrial traps. In addition, no above ground trap sets were included because of the lack of understorey. These variations in methodology resulted in unequal trapping effort. Sherman live traps and $15 \mathrm{~cm} \mathrm{X} 15 \mathrm{~cm} \mathrm{X} 30 \mathrm{~cm}$ wire live traps were used in both $\mathrm{RD} / \mathrm{P}$ and $\mathrm{RD} / \mathrm{E}$. In $\mathrm{RD} / \mathrm{E}$ these were placed on the ground and in arborescent vegetation along with 16 larger ( $30 \mathrm{~cm} \mathrm{x} 40 \mathrm{~cm} \mathrm{x} 60 \mathrm{~cm}$ ) wire traps placed on the ground. Trapping details are described in STALLINGS (1989). 


\section{RIO DOCE STATE FORESTRY PARK}
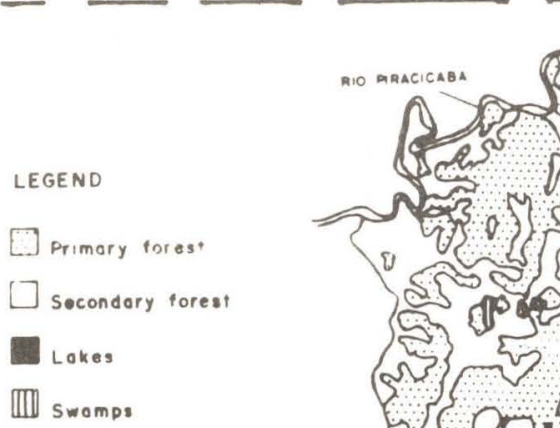
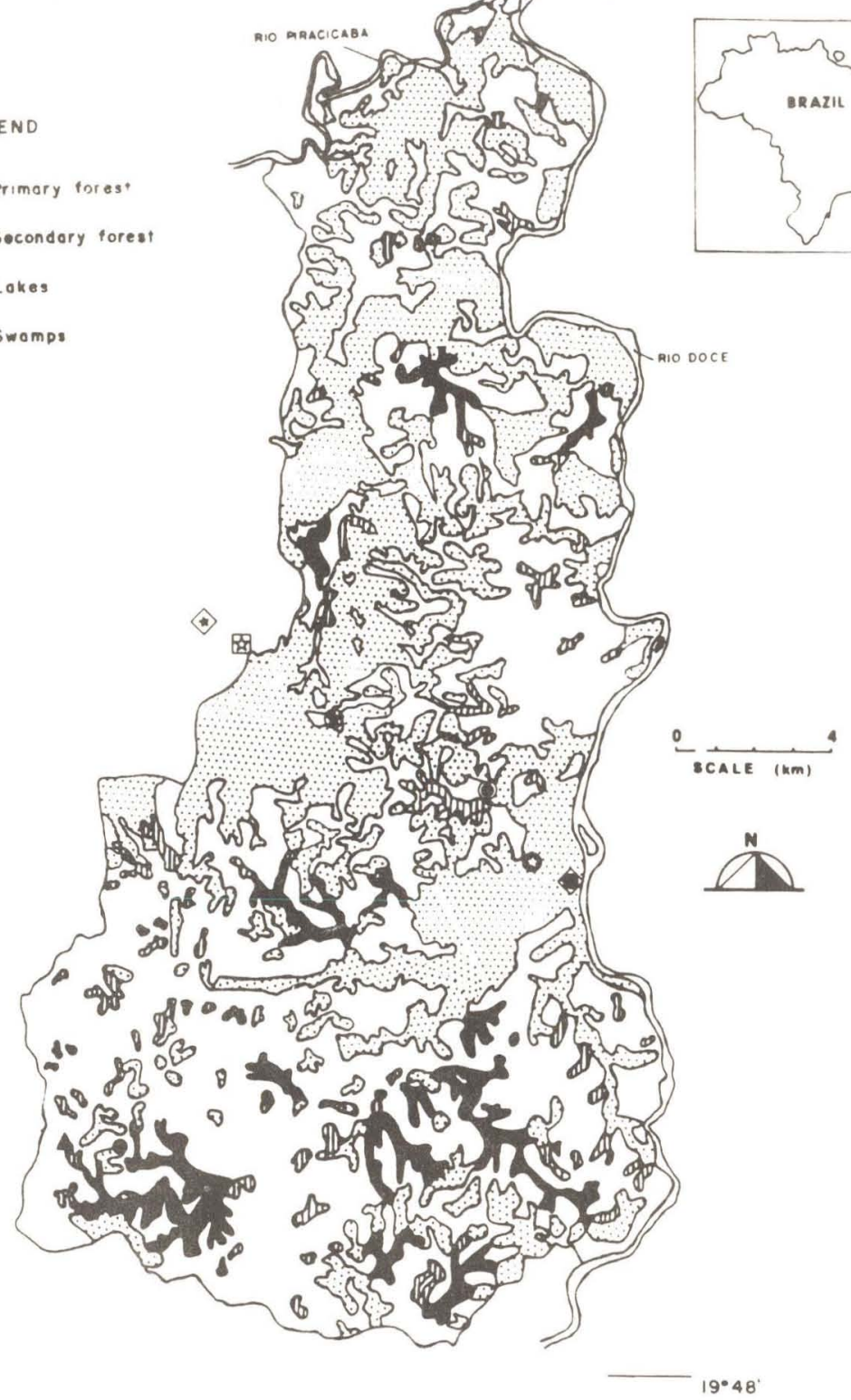

Figure 1. Map of the Rio Doce State Forestry Park indicating habitat types within the Park and collecting areas outside of the Park in eucalypt habitat: $=\mathrm{RD} / \mathrm{P} ;=\mathrm{RD} / \mathrm{E}$. 


\section{Medium and Large Sized Birds and Mammals}

Medium and large vertebrates were recorded by conducting repeat transect censuses. The trail system in $\mathrm{RD} / \mathrm{E}$ was approximately $1.0 \mathrm{~km}$ in length and was walked 60 times during the study. The trail system in $\mathrm{RD} / \mathrm{P}$ was $300 \mathrm{~m}$ and was walked 20 times during the study. Surveys were carried out between 07.00 and 12.00 hours. When encountering an animal the following data were recorded: species, perpendicular distance from the trail, height in tree, group size, location, and time.

In addition to census transects, animal spoor, such as tracks and scat piles, were recorded to identify the presence of species that were either nocturnal or unlikely to be encountered during moming censuses.

\section{RESULTS}

\section{Small Mammal Captures}

Fifty-three individuals of seven species of small mammals were caught in 6000 trap nights in the stand with native species understorey $\mathrm{RD} / \mathrm{E}$. Only one animal was captured in 500 trap nights in the homogeneous eucalypt forest $\mathrm{RD} / \mathrm{P}$ (Table 1). Trapping success in $\mathrm{RD} / \mathrm{E}$ was $2,6 \%$ and only $0,2 \%$ in $\mathrm{RD} / \mathrm{P}$.

Didelphid marsupials accounted for $82,7 \%$ of the total captures in RD/E (Table 1). Marmosa cinerea was the marsupial species captured most frequently, and, Metachirus nudicaudatus, Marmosa incana and Caluromys philander were also well represented. Akodon cursor was the rodent species captured most frequently.

In $\mathrm{RD} / \mathrm{E}$, the number of species recorded per month ranged from two to five. The cumulative number of species remained constant from the 8 th month till the end of the study. Small mammal captures were recorded at 43 of the available 48 stations in $\mathrm{RD} / \mathrm{E}$ $(89,6 \%)$, however, roughly half (77) of the captures were at only 10 stations. Approximately half $(52 \%)$ of the 53 individuals were captured at least twice. Individuals of some species were frequently recaptured. Eight of the 9 Marmosa cinerea were recaptured. Four individuals accounted for 60 of the 77 captures, and one was captured on 21 occasions during nine months.

Upon release, arboreal marsupials, Marmosa cinerea, Marmosa incana and Caluromys philander either remained on the ground or climbed the arborescent vegetation of the understorey. No individuals were observed to climb or move through the eucalypt trees.

\section{Other Vertebrates}

Table 2 lists the species that were sighted or detected by the presence of spoor in RD/E. Sightings included the red brocket deer (Mazama sp.), tapir (Tapirus terrestris), dusky legged guan (Penelope obscura), tayra (Eira barbara), and tinamou (Crypturellus $s p$.). P. obscura was the species most frequently observed. Spoor was also observed for the following species: Felis sp., Dusicyon gymnocercus, Nasua nasua, and Procyon cancrivorus. Primates were not observed in either area, and no medium sized or large birds or mammals were recorded for $\mathrm{RD} / \mathrm{P}$. 


\section{TABELA 1}

Capture results of small mammals from homogeneous eucalypt forest and eucalypt forest with native species understorey near the Rio Doce State Forestry Park, Minas Gerais, Brazil. Recap Index = total captures/first captures and represents the average number of times that an individual was captured. Recap Index $1=$ results from this study. Recap Index 2 = results from native forest captures in the Park and are taken from STALLINGS (1989).

Homogeneous Eucalypt Forest (RD/P)

\begin{tabular}{|c|c|c|}
\hline Species & $\begin{array}{l}\text { Total } \\
\text { Capture }\end{array}$ & $\%$ Total \\
\hline
\end{tabular}

\section{Rodents}

Oryzomys nigripes

$1 \quad 100$

1.0

Eucalypt Forest with Native Species Understorey $(\mathrm{RD} / \mathrm{E})$

Marsupials

Didelphis marsuapilis

Metachirus nudicaudutus

Marmosa incana

Marmosa cinerea

Caluromys philander

$\begin{array}{rrr}7 & 4.5 & 3 \\ 17 & 10.8 & 9 \\ 14 & 9.0 & 8 \\ 75 & 48.1 & 9 \\ 16 & 10.3 & 6 \\ 129 & 82.7 & 35\end{array}$

Rodents

Akodon cursor

Oryzomys capito

$\begin{array}{rrrrr}25 & 16.0 & 16 & 1.5 & 1.9 \\ 2 & 1.3 & 2 & 1.0 & 1.2 \\ 27 & 17.3 & 18 & & \end{array}$

\section{DISCUSSION}

The majority of the small mammals captured in the eucalypt stand with native species understorey $(\mathrm{RD} / \mathrm{E})$ were clearly using the area and their presence was not due to marginal movements at range border's nor due to individuals passing through the area. These data can be compared to the recapture rates of the same taxa in the native forest of the Rio Doce Park (Table 1). Recapture rates in RD/E were much higher and indicate that these species have less freedom of movement in $\mathrm{RD} / \mathrm{E}$ (STALLINGS, 1989).

Six of the seven species of small mammals in $\mathrm{RD} / \mathrm{E}$ are considered forest species. Akodon cursor was the only one that is considered a pioneer species, occurring in high densities in grass/open habitats and in early secondary growth habitats (STALLINGS, 1989). The other species range from terrestrial to highly arboreal and, in the Rio Doce Park, were captured in habitats ranging from secondary to primary forest. Caluromys was captured only in second growth and primary forest, and only by using arboreal traps at a mean height of $11 \mathrm{~m}$. The mean height of the arboreal traps in RD/E was $1 \mathrm{~m}$. These capture results demonstrate that the native species understorey of this eucalypt stand offer habitat suitable for pioneer, forest adapted and even highly arboreal species. 
The percentage of marsupial captures in the Park and RD/E was remarkably similar: $82,7 \%$ and $82,8 \%$, respectively (STALLINGS, 1989). However, the species composition of small mammals in RD/E differed from that of native forest in the Park, most importantly in the lack of rodents in RD/E. The semi-aquatic Nectomys squamipes and semifossorial Oxymycterus roberti were not found in the $\mathrm{RD} / \mathrm{E}$ forest, even though a wet low area bordered one side of the plantation and represented suitable habitat for these species. Also absent from $\mathrm{RD} / \mathrm{E}$ were Rhipidomys mastacalis and Oecomys trinitatis, arboreal and scansorial rodents, respectively (STALLINGS, 1989). Why these species were absent is difficult to say considering the presence of other arboreal and scansorial species (marsupials). One possible explanation is that food resources in the eucalypt forest with native species understorey might be limiting and since marsupials have more generalized diets, they might be able to out compete rodents with stricter diets. Another explanation may be that the physical barriers between the Park and the native species understorey stand prevent successful colonization.

The results of the census transects and spoor counts showed that several species of medium to large sized birds and mammals were using the habitat in RD/E. However, these data did not reveal whether they depended on the mixed species understorey stand as did some of the small mammals, or whether they used the area only occasionally. STALLINGS (1988) conducted census transects in the Park and found more species in this habitat in comparison to the understorey in $\mathrm{RD} / \mathrm{E}$ (Table 2).

The major difference between Park and $\mathrm{RD} / \mathrm{E}$ was the lack of primates in the latter. In the Park, primates occur in all of the native forest sites (STALLINGS, 1988). GANZHORN $(1985,1987)$ reported prosimians in eucalypt forests with a sbucanopy in Madagascar. Langurs, macaques and gibbons have been observed to use plantations of Eucalyptus, Albizia, and Gmelina in Sabah (DUFF et al., 1984). One explanation for the absence of primates in the RD/E site may be attributed to the narrow width of the subcanopy habitat. Essentially, the subcanopy habitat was a narrow band of lower stratum secondary forest with an upper stratum of homogeneous eucalypt forest. In addition, primates may not have used the area because of the distance of the subcanopy habitat from the native forest in Park. The trapping site abutted the Park but was separated by a wide, low, wet area of approximately $400 \mathrm{~m}$.

FOX AND MCKAY (1981) argued that small mammals respond to the understorey in plantations (eucalypt) in a similar fashion as they do to early secondary native species habitats. This is corroborated by this study, and its is evident that small mammal populations are higher in spatially heterogeneous habitats than in relatively homogeneous forest such as $\mathrm{RD} / \mathrm{P}$. The same is true for a number of larger species of mammals and birds.. A native species understorey can provide the food, shelter, and resting sites for wildlife species that occur in native forest.

Recent studies have emphasized the importance of secondary forests to wildlife in southeastern Brazil (e.g. FONSECA, 1985b; 1988; 1989; FONSECA AND KIERULFF, 1989; STALLINGS, 1988; 1989; STALLINGS et al., in press). Species diversity of small mammals and relative abundances of other vertebrates (medium and large sized birds and mammals) were found to be higer in homogeneous and mosaic secondary habitats than in primary forests. This is not to say that primary forests were originally depauperate relative to secondary habitats: rather that in many areas of the tropics we are left with secondary habitats that might be quite rich in wildlife. The importance of the understorey, whether in plantations or secondary forests, is one aspect of tropical forest ecology that has been sorely neglected. 
TABELA 2

Species of medium and large sized birds and mammals occuring in a homogeneous eucalypt stand $(\mathrm{RD} / \mathrm{P})$, eucalypt with native species understorey stand $(\mathrm{RD} / \mathrm{E})$ and native species secondary and primary forests stands in the Rio Doce State Forestry Park. Data for native species forests in the Park are taken from STALLINGS (1988).
Species
$\mathbf{R D} / \mathbf{P} \quad \mathbf{R D} / \mathbf{E}$
Secondary
Primary

Mammals

Callicebus personatus

Cebus apella

Callithrix aurita

Brachyteles arachnoides

Sciurus aestuans

Dasyprocta azarae

Agouti paca

Nasua nasua

Procyon cancrivorus

Felis pardalis

Felis concolor

Felis sp.

Eira barbara

Dusicyon gymnocercus

Mazama sp.

Tapirus terrestris

Total

0

$\begin{array}{ccc} & \mathrm{X} & \\ & \mathrm{X} & \mathrm{X} \\ & \mathrm{X} & \\ \mathrm{X} & \mathrm{X} & \mathrm{X} \\ & \mathrm{X} & \mathrm{X} \\ & \mathrm{X} & \mathrm{X} \\ & \mathrm{X} & \mathrm{X} \\ \mathrm{X} & \mathrm{X} & \mathrm{X} \\ & \mathrm{X} & \mathrm{X} \\ \mathrm{X} & \mathrm{X} & \mathrm{X} \\ \mathrm{X} & \mathrm{X} & \mathrm{X} \\ \mathrm{X} & \mathrm{X} & \mathrm{X} \\ \mathrm{X} & \mathrm{X} & \mathrm{X} \\ \mathrm{X} & \mathrm{X} & \\ 6 & 15 & \end{array}$

Birds

Nothura sp.

Crypturellus sp.

Penelope obscura

Tinamus solitarius

Odontophorus sp.

Total

Grand total

$\begin{array}{rrrr} & & \mathrm{X} & \mathrm{X} \\ & \mathrm{X} & \mathrm{X} & \mathrm{X} \\ \mathrm{X} & \mathrm{X} & \mathrm{X} \\ & & \mathrm{X} & \mathrm{X} \\ & & 5 & \\ 0 & 2 & 20 & 4 \\ 0 & 8 & & 16\end{array}$

\section{Management and Conservation Implications}

Even though it has been demonstrated that monocultural plantations of native or exotic tree species do not harbor appreciable amounts of wildlife, some authors have proposed that these plantations could be used to raise certain game species. SMITH (1978; 1981) proposed that since brocket deer (Mazama spp.) and the brazilian tapir (Tapirus terrestris) eat fruit, plantation schemes that produce edeible fruit (such as Gmelina arborea) would provide a food resource for these species. While it is true that a substantial portion of these species diets consists of fruit (STALLINGS, 1983; NOWAK AND PARADISO, 1982), I would argue that leaves and browse are of equal importance. In addition, Gmelina is not extensively planted in Brazil and fruit production is limited to a specific period during the year. Likewise, tapir and deer could not be permitted to browse the stems of the plantation species for fear of damaging the trees. Even if animals were allowed to browse, plantation species, such as Eucalyptus, would not provide the leaf material necessary for these species because of the heavy toxins that are present in leaves. 
T. Smith (cited in EVANS, 1982) suggested that there should be no difference in the biomass of terrestrial vertebrates in homogeneous plantations and in native mature forests because vertebrate biomass is low on the tropical forest floor. EISENBERG AND THORINGTON (1973) indicated that a large portion of the neotropical vertebrate biomass is tied up in the forest canopy. However, native forests and homogeneous plantations differ not only in the species richness of the arborescent vegetation (which by association offers a variety of food resources), but also spatially, which in the former, is patchier and more complex offering more food resources, cover and resting sites for terrestrial vertebrates.

DIETZ et al. (1975) reported on the effect of homogeneous plantations on small mammal communities in Minas Gerais, Brazil. They found that relative abundances of small mammals were higher in a homogeneous native species plantation of Araucaria angustifolia, intermediate in two native forest habitats, and lowest in a homogeneous exotic species plantation of Eucalyptus saligna. Four of the five species captured during their study are considered pioneers. Two of them, Oryzomys nigripes and Akodon cursor, represented $81 \%$ and $14 \%$ of all captures in all forest types, respectfully. The authors found a higher species diversity (number of species) in the native sites. EVANS (1982) interpreted these results as positive effects of plantations on wildlife, and suggested that native species plantations should be used when possible. Small mammals, usually early pioneer species, can find refuge in the grass substrate within a homogeneous plantation. However, if the conservation goal is to preserve the wildlife that occurs in the native forested areas, then monocultures of exotic or native tree species are not adequate. Mixed species stands can be an option to harbor species that are displaced due to forestry operations and plantation schemes.

There are approximately 15,000 ha. of eucalypt plantations surrounding the Rio Doce Park. If plantation managers were to allow the understorey to develop in forests near the perimeter of the park, a buffer zone of mixed species eucalypt forest could effectively increase the area of the park for many wildlife species. A strategic policy of harvest rotation would insure that a significant portion of the eucalypt forest with native species understorey remain at all times. In addition, this type of management could be used to create wildlife corridors within plantations, to divide different aged stands or to operate as living fences to designate property boundaries. Wildlife corridors could provide small mammals adequate habitat to establish territories and could furnish large vertebrates the cover to move from one area to another.

\section{ACKNOWLEDGMENTS}

This study was funded by a Fellowship from the Organization of American States and the Program for Studies in Tropical Conservation. Logistical support was provided by the Instituto Estadual de Florestas de Minas Gerais and through the Laboratorio de Mastozoologia, Departamento de Zoologia, Universidade Federal de Minas Gerais. I thank Alair Lopes de Freitas, Eng. Florestal with the Acesita Energetica, for allowing me to sample the eucalypt forests, and to Ademir Camara Lopes, Park Administrator of PFERD, for graciously supporting my work in the Park.

I am especially grateful to John G. Robinson and Kent H. Redford for encouranging me to sample the eucalypt forests. Gustavo Fonseca and his field team helped to collect some of the data presented in this paper. Many field assistants from the Federal 
University of Minas Gerais participated directly in this project. I thank Lucio C. Bede, Ludimilla Aguiar, Luiz Paulo de Souza Pinto and Eduardo Lima Sabato. Kent Redford, Gustavo Fonseca and two anonymous reviewers improved the manuscript substantially.

\section{REFERÊNCIAS BIBLIOGRÁFICAS}

ALMEIDA, A.F. 1979. Influência do tipo da vegetação nas populaçōes de aves em uma floresta implantada de Pinus spp., na região de Agudos, SP. Silvicultura, Anais do 3. Congresso Florestal Brasileiro, Volume II.

BAER, W. 1970. The Development of the Brazilian Steel Industry. Zahar Editores, Rio, 243 pp.

BAILEY, J.A., AND M. M. ALEXANDER. 1960. Use of closed conifer plantations by wildlife. N. Y. Fish and Game J. 7: 130-148.

DIETZ, J.M., COUTO, E.A., ALFENAS, A.C., FACCINI, A., AND G.F. DA SILVA. 1975. Efeitos de duas plantações de florestas homogêneas sobre populações de mamíferos pequenos. Brasil Florestal 6 (23): 53-57.

DUFF, A.B., HALL, R.A., AND C.W. MARSH. 1984. A survey of wildlife in and around a commercial tree plantation in Sabah. The Malaysian Forester 47 (3): 197-213.

EISENBERG, J.F., AND R.W. THORINGTON. 1973. A prèliminary analysis of a neotropical mammal fauna. Biotropica 5 (3): 150-161.

EVANS, J. 1982. Plantation Forestry in the Tropics. Clarendon Press, Oxford. $472 \mathrm{pp}$

FONSECA, G.A.B. 1985a. The vanishing Brazilian Atlantic Forest. Biol. Conservation. 34 (1): $17-34$.

FONSECA, G.A.B. 1985b. Observations on the ecology of the muriqui (Brachyteles arachnoides E. Geoffroy 1806): implications for its conservation. Primate Conservation 5: 48-52.

FONSECA, G.A.B. 1988. Patterns of small mammal species in the Brazilian Atlantic Forest. Unpubl. Doctoral Dissertation, University of Florida, Gainesville. 232 pp.

FONSECA, G.A.B. 1989. Small mammal species diversity in brazilian tropical primary and secondary forests of different sizes. Revta. Brasil. Zool. 6 (3): 381-422.

FONSECA, G.A.B. AND M.C.M. KIERULFF. 1989. Biology and natural history of brazilian A tlantic Forest small mammals. Bull. Flor. St. Mus., Biol. Sci., 34 (3): 99-152.

FOX, B.J., AND G.M. MCKAY. 1981. Small mammal responses to pyric successional changes in eucalypt forest. Austr. J. Ecol. 6: 29-41.

FRIEND, G.R., AND J.A. TAYLOR. 1985. Habitat preferences of small mammals in tropical openforest of the North Territory. Austr. J. Ecol. 10:173-185.

GANZHORN, J.U. 1985. Utilization of eucalyptus and pine plantations by brown lemurs (Lemur $\mathrm{f}$. fulvus) in the eastern rainforest of Madagascar. Primate Conservation 6:34-35.

GANZHORN, J.U. 1987. A possible role of plantations for primate conservation. Amer. J. Primatol. 12: 205-215.

HARRIS, L.D., AND W.H. SMITH. 1978. Relations of forest practices to non-timber resources and adjacent ecosystems Pages 28-53 in: Productivity on prepared Sites (T. Tappen, ed.). USDA, Forest Service, New Orleans, LA.

IBGE. 1986. Anuario Estadistico do Brasil, 1985. Fundação Inst. Bras. de Geo. Estat. Brasília.

JOHNS, A.D. 1987. The use of primary and selectively logged rainforest by Malaysian Hornbills (Bucerotidae) and implications for their conservation. Biol. Conservation 40:179-190.

LOPES, A.C. 1983. Proposta de plano diretor do Parque Estadual Rio Doce. Instituto Estadual de Florestas, M.G., Brazil.

NATIONAL ACADEMY PRESS. 1982. Impacts of Emerging Agricultural Trends on Fish and Wildlife Habitat. Washington, D.C. 303 pp.

NOWAK, R.M., AND J.L. PARADISO. 1983. Walker's Mammals of the World. 4 th Edition. The John Hopkins University Press, Baltimore.

ODENDAAL, P.B., AND R.C. BIGALKE. 1979. Habitat selection by bushbuck in a disturbed environment. S. Afr. For. J. 108: 39-41.

SMITH, N.J.H. 1978. Human exploitation of terra firme fauna in Amazonia. Cienc. e cult., 30 (1): $17-23$.

SMITH, N.J.H. 1981. Hunters of the Amazon. Wildlife. August 32-38.

STALLINGS, J.R. 1983. Notes on feeding habits of Mazama gouazoubira in the Chaco Boreal of Paraguay. Biotropica 16 (2): 155-157. 
STALLINGS, J.R. 1988. Small mammal communities in an eastern Brazilian park. Unpub. Doctoral Dissertation, University of Florida, Gainesville, $200 \mathrm{pp}$.

STALLINGS, J.R. 1989. Small mammal inventories in an eastern Brazilian Park. Bull. Flor. St. Mus., Biol. Sci., 34 (4): 153-200.

STALLINGS, J.R., L.P. de SOUZA PINTO, L. AGUIAR AND E.L. SABATO. In press. A importância de distúrbios intermediários na manutenção de diversidade da fauna em uma floresta tropical. Annais do Encontro de Ecologia Evolutiva, Rio Claro, São Paulo.

WADSWORTH, F.H. 1961. Eucalyptus progress in Latin America. Second World Eucalyptus Conference, Report and Documents. Vol. 1:165-171.

WILSON, W.L., AND A.D. JOHNS. 1982. Diversity and abundance of selected animal species in undisturbed forest, selectively logged forest and plantations in East Kalimantan, Indonesia. Biol. Conservation 24: 205-218. 